\title{
KRITERIA ALOKASI TANGKAPAN TUNA UNTUK KOMISI TUNA SAMUDERA HINDIA (IOTC)
}

\author{
Tuna Catch Allocation Criteria for The Indian Ocean Tuna Commission (IOTC)
}

Oleh:

\author{
Darmawan $^{1 *}$, Aditya Setianingtyas ${ }^{2}$, M. Fedi A. Sondita ${ }^{3}$ \\ 1Departemen Pemanfaatan Sumberdaya Perikanan, FPIK-IPB. darmawan@indo.net.id \\ 2Alumni Departemen Pemanfaatan Sumberdaya Perikanan, FPIK-IPB. aditya.setianingtyas@gmail.com \\ ${ }^{1}$ Departemen Pemanfaatan Sumberdaya Perikanan, FPIK-IPB. fsondita@indo.net.id \\ *Korespondensi:darmawan@indo.net.id
}

Diterima: 22 September 2017; Disetujui: 6 Juni 2018

\begin{abstract}
Catch allocation scheme generally establish based on country's historic catch data. Growing membership from coastal states in the Indian Ocean Tuna Commission (IOTC), raise issue about the importance of geographical position in determining a catch allocation criteria. In 2009, Scientific Committee of IOTC estimated that landings of yellowfin tuna and bigeye tuna had nearly or even exceeded its maximum sustainable yield (MSY). Therefore, in 2010, IOTC adopted resolution to establish a system and criteria on allocation of catch for yellow fin and bigeye tuna and invited member countries to submit proposal. Indonesia proposes criteria on historic catch, economic dependency toward tuna, coastal state status, bio-ecological significance of the fishing ground, IOTC membership and level of compliance. Japan, which represents the state longdistance fishing, proposes historic catch, sustainable management plan, IOTC membership, level of compliance, financial contribution, contribution to research and data collection, and utilization of allocated quota. Objective of the research is to analyse comparation of both proposals with regards to coastal states' rights and jurisdiction in accord with UNCLOS 1982 and resource management rights concept in Schlager and Ostrom (1992). The research used a qualitative approach in which literature and report reviews had been conducted as data collection method, strengthened with depth interviews of resource persons, particularly Indonesia's delegates and other relevant parties. Data obtained were analyzed descriptively using simulation calculations according to the proposed criteria. Results show that Indonesian proposed criteriaprovide advantages for coastal states, but will be disadvantaged for Japan and other distant fishing countries. It needs an approach and further deliberation to reach agreement on tuna catch allocation criteria in the IOTC.
\end{abstract}

Keywords: catch allocation criteria, coastal states, management rights

\begin{abstract}
ABSTRAK
Skema alokasi kuota tangkapan seringkali ditentukan berdasarkan catatan sejarah hasil tangkapan armada tiap negara. Meningkatnya keanggotaan Indian Ocean Tuna Commission (IOTC) yang berasal dari negara pantai di Samudera Hindia, menjadikan kriteria alokasi tangkapan berdasarkan posisi geografis menjadi isu yang sangat penting. Pada tahun 2009, stok tuna sirip kuning (yellowfin) dan tuna mata besar (bigeye) di Samudera Hindia diduga telah mendekati atau bahkan melebihi perkiraan nilai maximum sustainable yield (MSY) nya. Oleh sebab itu tahun 2010, IOTC mengeluarkan resolusi untuk menyusun sistem dan kriteria alokasi tangkapan dan meminta usulan proposal. Kriteria yang diusulkan Indonesia meliputi sejarah penangkapan, ketergantungan
\end{abstract}


ekonomi terhadap tuna, posisi negara pantai, signifikansi perairan negara, keanggotaan IOTC dan tingkat kepatuhan. Adapun Jepang yang mewakili negara penangkap ikan jarak jauh mengusung kriteria sejarah penangkapan, rencana perikanan berkelanjutan, keanggotaan IOTC, tingkat kepatuhan, kontribusi keuangan, kontribusi pada riset dan pendataan serta tingkat pemanfaatan alokasi kuota. Penelitian ini bertujuan membandingkan kriteria kedua usulan tersebut dari sudut pandang hak-hak negara pantai dalam konvensi hukum laut internasional dan konsep kepemilikan sumber daya ikan (Schlager dan Ostrom 1992). Penelitian dilakukan melalui pendekatan kualitatif dimana data dan informasi diperoleh melalui kajian pustaka dan wawancara terhadap ketua atau anggota delegasi Indonesia serta pihak-pihak terkait lainnya. Data yang diperoleh dianalisis secara deskriptif dengan menggunakan simulasi perhitungan sesuai kriteria yang diusulkan. Hasil penelitian menunjukkan bahwa kriteria yang diusulkan Indonesia lebih menguntungkan bagi Indonesia, tetapi membuat Jepang dan negara penangkap ikan jarak jauh sulit untuk menerimanya. Diperlukan pendekatan dan diskusi lebih lanjut untuk mencapai kesepakatan kriteria alokasi tangkapan tuna di IOTC.

Kata kunci: kriteria alokasi tangkapan, negara pantai, hak pengelolaan

\section{PENDAHULUAN}

Laporan Scientific Committee dari Indian Ocean Tuna Commision (IOTC) pada tahun 2009 memperkirakan rata-rata penangkapan tahun 2004 sampai 2008 untuk bigeye tuna sebesar 121.700 ton dan yellowfin tuna sebesar 410.800 ton. Jumlah tersebut ternyata telah melebihi estimasi jumlah Maximum Sustainable Yield (MSY) yaitu sekitar 110.000 untuk bigeye tuna dan 300.000 ton untuk yellowfin tuna (IOTC 2009). Laporan tersebut menjadi pemicu bagi IOTC untuk mengadopsi resolusi 10/01 untuk konservasi dan pengelolaan stok tuna di wilayah tropis dalam sidangnya yang ke 14 (empat belas) di Busan, Korea Selatan tahun 2010 (IOTC 2010). Salah satu isi dari resolusi tersebut adalah menetapkan perlu diadakannya pertemuan teknis untuk membahas kriteria pengalokasian kuota dan merekomendasikan sistem pengalokasian kuota ataupun cara dan mekanisme lainnya yang serupa untuk ikan tuna sirip kuning dan tuna mata besar (IOTC 2010). Pengalokasian kuota merupakan skema yang umum digunakan dalam pengelolaan sumber daya ikan (Aranda et al. 2012; Bailey et al. 2014; Lyndham 2014). Untuk itu IOTC membentuk Komisi Teknis untuk menyusun kriteria alokasi tuna dan mengundang anggotanya untuk menyampaikan proposal untuk dibahas bersama.

Menurut Nurani et al. (2013) komoditi ekspor utama Indonesia selain udang adalah ikan tuna. Tuna banyak ditangkap dengan alat tangkap longline dan pancing tonda (Wardono 2016). Pada masa itu, rata-rata hasil tangkapan tuna sirip kuning Indonesia selama tahun 20082010 adalah 35.396 ton dan 17.023 ton untuk tuna mata besar (Irianto et al. 2015). Hasil ini berturut-turut adalah $11,8 \%$ dan $15,5 \%$ dari angka MSY tuna sirip kuning dan tuna mata besar IOTC. Jumlah tersebut menunjukkan kecenderungan meningkat sampai dengan tahun 2014 (Irianto et al. 2015). Angka-angka tersebut menunjukkan bahwa Indonesia sangat berkepentingan untuk dapat memastikan perolehan alokasi jumlah kuota sesuai dengan profil hasil tangkapannya selama ini (Noye dan Mfodwo 2012). Namun demikian Gigentika et al. (2017) berpendapat bahwa pemanfaatan tuna di Indonesia belum mempunyai sistem yang baik. Lebih lanjut dikatakan bahwa keterpaduan dan sinergi beberapa aspek seperti teknologi, sosial, kelembagaan, dan sumber daya manusia sangatlah diperlukan dalam menyusun sistem pemanfaatan yang berkelanjutan.

Keanggotaan IOTC terdiri dari negaranegara pantai di Samudera Hindia dan juga negara-negara maju dengan armada penangkapan ikan jarak jauhnya (distant water fishing nations), antara lain Jepang dan negara-negara Uni Eropa. Kedua kelompok negara ini bersaing untuk menangkap tuna di Samudera Hindia (Gagern dan Van den Berg 2013; Nichols et al. 2015; Queirolo dan Johnston 1989). Negaranegara maju tersebut telah terlebih dahulu memanfaatkan sumber daya tuna di Perairan Samudera Hindia dan memiliki sistem pencatatan yang jauh lebih lengkap.

Jepang memiliki posisi yang unik karena menjadi negara penghasil ikan terbesar dunia, sekaligus salah satu negara pengimpor ikan terbesar (Hidayati et al. 2015). Kepentingan Jepang mempertahankan keanggotaannya di IOTC selain untuk menjamin keberlanjutan kehadiran armada-armada penangkapannya, juga memastikan pasokan tuna ke pasaran domestiknya.

Jepang bersama negara-negara Uni Eropa menyampaikan usulan kriteria alokasi kuota pada pertemuan Komisi Teknik pertama di Nai- 
robi, Kenya tahun 2011 dan pertemuan kedua di Muskat, Oman tahun 2013 (IOTC 2012). Walaupun pada pertemuan ke tiga di Iran tahun 2016, Jepang tidak lagi menyampaikan usulannya (IOTC 2016), namun usulan mereka dalam dua pertemuan sebelumnya perlu dipelajari karena dapat dianggap mewakili suara atau kepentingan negara-negara maju pemilik armada perikanan jarak jauh. Adapun Indonesia sebagai negara berkembang sekaligus negara pantai di Samudera Hindia dapat dianggap mewakili kepentingan negara-negara anggota IOTC yang wilayah Zona Ekonomi Eksklusifnya menjadi daerah penangkapan ikan tuna tersebut. Perbandingan usulan kriteria alokasi kuota dari dua kubu negara anggota IOTC diperlukan untuk dapat mencari titik temu atau kompromi diantara keduanya.

Negara-negara dengan kawasan ZEE yang dijadikan daerah penangkapan ikan armada internasional, seperti Indonesia, sudah sewajarnya menyadari keunggulan dan kelemahan dari kriteria yang diusulkannya. Kesadaran ini penting agar mereka dapat menyiapkan diri mengantisipasi berbagai konsekuensi yang akan timbul segera setelah kompromi tercapai. Bagi Indonesia, kompromi tersebut harus disikapi dengan antisipasi memanfaatkan peluang baru yang muncul sebagai konsekuensi dari kompromi tersebut. Kegagalan dalam mengidentifikasi keunggulan dan kelemahan kriteria yang diusulkan serta peluang-peluang baru akan menyebabkan ketidak-siapan Indonesia dalam bernegosiasi dengan pihak-pihak lain dalam hasil pemanfaatan sumberdaya ikan global, khususnya yang ada di Zona Ekonomi Ekslusif.

Penelitian ini bertujuan membandingkan kedua usulan kriteria alokasi dari negara anggota IOTC tersebut dengan menggunakan pertimbangan hak-hak negara pantai dalam konvensi hukum laut internasional dan konsep kepemilikan sumber daya ikan menurut Schlager dan Ostrom (1992). Hasil penelitian ini dapat digunakan untuk menyusun strategi atau memperkuat arguman kriteria alokasi kuota yang diusung Indonesia.

Pengumpulan data/informasi dilakukan melalui kajian pustaka dan wawancara dari beberapa anggota/ketua delegasi Indonesia yang menghadiri pertemuan teknis IOTC tersebut. Kajian pustaka dilakukan terhadap laporan hasil-hasil perundingan di setiap pertemuan Komisi Teknik sebagaimana dipublikasikan dalam situs web resmi IOTC. Informasi lain diperoleh melalui wawancara dan komunikasi langsung dengan nara sumber di Indonesia yang terlibat dalam negosiasi kriteria alokasi tuna, ataupun menjadi anggota delegasi Indonesia (Direktorat
Sumber Daya Ikan Kementerian Kelautan dan Perikanan, Badan Penelitian dan Pengembangan Kementerian Kelautan dan Perikanan, Pusat Penelitian Pengelolaan Perikanan dan Konservasi Sumber Daya Ikan) dalam pertemuan-pertemuan Komisi Teknik pertama di Kenya tahun 2011, kedua di Oman tahun 2013 maupun ketiga di Iran tahun 2016. Laporan hasil pertemuan Komisi Teknis tentang Kriteria Alokasi yang diselenggarakan di Seychelles pada Februari 2018 digunakan sebagai deskripsi kondisi terakhir perundingan mengenai hal ini. Informasi tambahan juga diperoleh melalui wawancara dengan pelaku usaha penangkapan ikan ASTUIN (Asosiasi Tuna Indonesia). Formulasi usulan kedua negara dianalisis secara deskriptif dengan menjelaskan keterkaitan satu variabel dengan variabel lainnya (Nazir 2014). Informasi mengenai kriteria alokasi kuota yang diajukan oleh Indonesia dan Jepang dianalisis secara deskriptif kualitatif. Selanjutnya untuk Indonesia, disandingkan dengan hasil wawancara terhadap nara sumber untuk mengkonfirmasi informasi yang diperoleh.

\section{METODE}

Penelitian ini dilakukan dalam beberapa tahapan sejak tahun 2014 sampai 2018 dengan menggunakan pendekatan kualitatif (Nazir 2014). Data yang dikumpulkan adalah: (1) kriteria dan formula yang diajukan delegasi Indonesia dan Jepang didalam sidang Komisi Teknis IOTC, (2) data yang relevan dengan indikator yang digunakan dalam setiap kriteria, dan (3) perspektif anggota delegasi Indonesia dalam sidang Komisi Teknis.

\section{HASIL \\ Usulan Kriteria Alokasi Kuota Tuna Indonesia}

Usulan Indonesia disampaikan pada Technical Committee on Allocation Criteria (TCAC) I tahun 2011 yang kemudian disempurnakan pada TCAC II tahun 2013 (IOTC 2013). Pada pertemuan TCAC III tahun 2016 usulan yang diajukan Indonesia tetap sama seperti saat TCAC II (IOTC 2016). Pada persidangan ke IV tahun 2018, ide awal dari usulan Indonesia mengenai perlunya kejelasan hak negara pantai disambut banyak negara pantai lainnya seperti Australia, Maladewa, Afrika Selatan, Seychelles, Pakistan, Srilanka, dan lainlain (IOTC 2018). Pada saat itu (TCAC IV), proposal yang diusung oleh banyak negara pantai sudah mengalami penyempurnaan lebih lanjut, namun pada intinya proposal Indonesia yang 
diajukan pada awal pertemuan Komisi Teknis terdiri dari tujuh kriteria alokasi kuota, yaitu (IOTC 2013):

\section{Sejarah Penangkapan}

Komisi IImiah IOTC menggunakan rentang data sejarah penangkapan selama lima tahun untuk menghitung rata-rata penangkapan tuna. Oleh karena itu, Indonesia mengusulkan sejarah penangkapan ikan selama lima tahun terakhir pada perhitungan alokasi kuota tuna khususnya yellowfin tuna dan bigeye tuna (Sunoko and Huang 2014).

2. Ketergantungan ekonomi negara terhadap sumber daya ikan

Negara yang ekonominya tergantung pada sumber daya ikan perlu mendapatkan alokasi yang lebih besar dibandingkan dengan negara yang ekonominya tidak bergantung pada sumber daya ikan. Bila negara tersebut memperoleh kuota yang kecil maka akan mempengaruhi perekonomian negara tersebut. Selain itu, kegiatan perikanan banyak menyerap tenaga kerja terutama bagi perikanan tradisional yang banyak mengandalkan tenaga manusia. Oleh karena itu, kriteria ini dapat direncanakan untuk membangun perekonomian negara kedepannya khususnya bagi nelayan. Kriteria ketergantungan ekonomi menjadi prioritas utama bagi Indonesia sehingga memiliki nilai pembobot terbesar. Bobot yang diberikan sebesar 0,30 untuk negara dengan ketergantungan tinggi; 0,25 ketergantungan menengah; 0,20 ketergantungan rendah.

\section{Indeks Pembangunan Manusia (IPM)}

IPM digunakan untuk mengkategorikan negara sebagai negara maju, negara berkembang atau negara terbelakang. Selain itu, IPM dapat digunakan untuk mengukur pengaruh kebijakan ekonomi terhadap kualitas hidup (UNDP 2015). Kriteria IPM diberi pembobotan yang cukup besar, yaitu negara terbelakang dengan nilai pembobot 0,20 ; negara berkembang 0,15; negara maju 0,10.

\section{Negara Pantai di Samudera Hindia}

Pasal 56 Konvensi Hukum Laut Internasional 1982 menetapkan pengakuanterhadap hak berdaulat Negara Pantai (coastal state) pada Zona Ekonomi Eksklusif (ZEE) untuk keperluan eksplorasi dan eksploitasi, konservasi sumberdaya alam, baik hayati maupun non hayati (UN 1982). Tiga Wilayah Pengelolaan Perikanan (WPP) Indonesia termasuk dalam area kompetensi IOTC, yaitu WPP 571, 572 dan 573. Oleh karena itu, Indonesia membe- rikan nilai pembobotan yang besar untuk kriteria ini. Negara pantai mendapatkan bobot sebesar 0,25 , sedangkan bukan negara pantai sebesar 0,15.

5. Signifikansi kondisi bio-ekologi perairan yang berada dalam yuridiksi negara pantai (tempat pemijahan, pembibitan dan jalur migrasi yang strategis)

Indonesia memberikan pembobotan yang cukup tinggi bagi negara dengan perairan yang memiliki bio-ekologi signifikan bagi tuna, yaitu sebesar 0,25 , sedangkan yang tidak memiliki sebesar 0,15.

\section{Keanggotaan IOTC}

IOTC mempunyai dua status keanggotaan, yaitu Negara Anggota (contracting Party) dan Negara Bekerja Sama Namun Bukan Anggota (non-Contracting Party). Negara anggota mendapat nilai pembobotan sebesar 0,90 sedangkan negara bukan anggota sebesar 0,85.

\section{Kepatuhan terhadap peraturan dan regulasi}

Memberikan kuota tangkapan yang lebih besar kepada negara yang mematuhi aturan, dapat menjadi penghargaan bagi negara yang mematuhinya. Negara yang patuh diberi nilai pembobot sebesar 0,1; parsial 0,05 dan tidak patuh 0 . Namun kriteria status keanggotaan negara mendapatkan bobot lebih besar dibandingkan tingkat kepatuhan negara. Hal ini karena melihat banyaknya negara khususnya coastal state yang masih kesulitan untuk meningkatkan nilai kepatuhannya termasuk Indonesia.

Langkah awal dalam perhitungan alokasi kuota tunamembutuhkan data tangkapan yang akurat dan dikumpulkan oleh komite ilmiah IOTC. Berikut rumusan formula perhitungan alokasi kuota tuna Indonesia (IOTC 2013):

$$
Q A i=A v e \_C a t c h i\left(W_{1}+W_{2}+W_{3}+W_{4}\right)\left(C F_{1}+C F_{2}\right) . .(1)
$$

dengan:

$$
\begin{aligned}
& Q A i \text { : alokasi kuota untuk masing-masing } \\
& \text { negara }
\end{aligned}
$$


Tabel 1 Pembobotan tiap kriteria alokasi kuota tuna

\begin{tabular}{llccc}
\hline Variabel & \multicolumn{1}{c}{ Kriteria } & \multicolumn{3}{c}{ Pembobotan } \\
\hline W1 & ketergantungan ekonomi & Tinggi & Sedang & Rendah \\
& terhadap sektor perikanan & 0,30 & 0,25 & 0,2 \\
W2 & indeks pembangunan manusia & Terbelakang & Berkembang & Maju \\
& & 0,20 & 0,15 & 0,10 \\
W3 & negara pantai di Samudera & Ya & & Tidak \\
& Hindia & 0,25 & & 0,15 \\
W4 & bio-ekologi yang terdapat di ZEE & Ya & & Tidak \\
& negara pantai & 0,25 & & 0,15 \\
CF1 & keanggotaan negara & Ya & & Tidak \\
& & 0,90 & 0,85 \\
CF2 & Tingkat kepatuhan & Patuh & Sebagian & Tak Patuh \\
& & 0,10 & 0,05 & 0 \\
\hline
\end{tabular}

Agar tidak melebihi TAC yang telah ditentukan maka perhitungan dilakukan dengan mengurangi $2,5 \%$ untuk stok cadangan. Dengan demikian perhitungan alokasi kuota untuk suatu negara adalah dengan membagi alokasi kuota negara tersebut dibagi dengan total seluruh kuota tangkapan yang didapatkan masing-masing negara anggota. Kemudian hasil pembagian tersebut dikali dengan $97,5 \%$ dari TAC keseluruhan (yang telah dikurangi 2,5\% untuk stok cadangan).

$\mathrm{QAi}_{\text {adjust }}=\frac{\mathrm{QAi}}{\mathrm{QA} 1+\mathrm{QA} 2+\mathrm{QA} 3+\cdots+\mathrm{QAn}} \times \mathrm{TAC} 97,5$

\section{Usulan Kriteria Alokasi Kuota Tuna Jepang}

Dasar perhitungan yang diajukan oleh Jepang dan didukung oleh Uni Eropa adalah total allowable catch (TAC) dari komite ilmiah IOTC. Jepang mengajukan tujuh kriteria alokasi kuota tuna yaitu (IOTC 2013):

1. Sejarah penangkapan dari anggota dan $c o-$ operating non-member (CPCs)

Sejarah penangkapan ikan yang digunakan untuk perhitungan rata-rata penangkapan adalah data 10 tahun ke belakang. Jepang telah mencatat hasil tangkapan sejak tahun 1950 sehingga dapat mengajukan rentang waktu yang lama untuk menghitung rata-rata hasil penangkapan.

2. Rencana perikanan berkelanjutan dari negara berkembang CPCs

3. Status keanggotaan (anggota dan cooperating non-member)

Dinilai dari keanggotaan, contracting party (CP) akan mendapatkan 100\%, sedangkan contracting non-party (CNP) akan mendapatkan $95 \%$.

4. Tingkat kepatuhan dengan konservasi dan pengelolaan perikanan
Negara yang patuh terhadap langkah-langkah konservasi dan pengelolaan akan diberikan $105 \%$ sedangkan yang tidak patuh $\geq 1$ akan diberikan $95 \%$ dan $90 \%$ akan diberikan untuk setiap kelebihan tangkapan alokasi ditambah dengan pengembalian kelebihan tangkapan tersebut.

5. Tingkat kepatuhan dalam kontribusi keuangan

Alokasi kuota tuna akan dikurangi setengah jika CPCs memiliki tunggakan $\geq 2$ tahun terakhir kontribusi keuangan. Persentasi sebesar $105 \%$ akan diberikan jika kontribusi finansial $\geq 100.000$ USD, sedangkan 100\% akan diberikan jika <100.000 USD.

6. Tingkat kontribusi pada riset dan pendataan

7. Tingkat pemanfaatan alokasi kuota tuna

Bila pemanfaatan alokasi kuota tuna yang telah diberikan pada tahun sebelumnya kurang dari $50 \%$ maka selanjutnya kuota yang akan diberikan menjadi $90 \%$.

Jepang juga memiliki TAC yang akan dicadangkan untuk pengembangan negara berkembang CPCs dan negara peserta bukan CPCs sebesar $3 \%$. Hal ini dimaksudkan untuk pengembangan alokasi cadangan. 3\% TAC yang dicadangkan untuk pengembangan perikanan akan ditingkatkan $1 \%$ setiap tahunnya hingga mencapai $12 \%$ selama 9 tahun.

Hasil perbandingan kriteria alokasi kuota Indonesia dan Jepang menunjukkan bahwa terdapat 4 (empat) kriteria alokasi kuota yang serupa yang diajukan oleh kedua negara yaitu: (a) sejarah penangkapan; (b) keanggotaan IOTC; dan (c) kepatuhan terhadap resolusi dan peraturan IOTC, dan (d) rencana perikanan berkelanjutan. Ada 4 (empat) kriteria alokasi kuota yang diajukan oleh Indonesia tapi bukan pertimbangan kriteria Jepang yaitu: (a) ketergantungan ekonomi negara terhadap perikanan; (b) negara pantai di Samudera Hindia; 
Tabel 2 Indikator kriteria alokasi kuota Jepang (IOTC 2013)

\begin{tabular}{clc}
\hline No & \multicolumn{1}{c}{ Indikator kriteria } & Kriteria Penilaian \\
\hline 1. & Keanggotaan IOTC & CP $=100 \%$ \\
& & CNP $=95 \%$ \\
\hline 2. & Kepatuhan terhadap resolusi & Patuh $=105 \%$ \\
& dan peraturan yang berlaku & Tidak patuh $=95 \%$ \\
& & Penangkapan melebihi kuota $=90 \%$ \\
& & serta pengembalian kelebihan tangkap \\
\hline 3. & Tunggakan kontribusi & Tunggakan $\geq 2$ tahun $=$ dikurangi $1 / 2(50 \%)$ \\
& keanggotaan (2 tahun) & Tunggakan $<2$ tahun $=$ tidak dikurangi \\
& & $(100 \%)$ \\
\hline 4. & Kontribusi finansial & $\geq 100,000$ US $\$=105 \%$ \\
& & $<100,000$ US $\$=100 \%$ \\
\hline 5. & Pemanfaatan alokasi & $\leq 50 \%=90 \%$ \\
& & $>50 \%=100 \%$ \\
\hline
\end{tabular}

(c) signifikansi bio-ekologi perairan; dan (d) Indeks Pembangunan Manusia (IPM). Adapun usulan kriteria alokasi Jepang yang tidak diperhitungkan oleh Indonesia adalah mengenai: (a) pemanfaatan alokasi kuota tuna; (b) tunggakan kontribusi; (c) besaran kontribusi finansial; dan (d) kontribusi pada penelitian dan pendataan.

\section{PEMBAHASAN}

Memasuki masa perundingan TCAC IV di Seychelles 2018, proposal penentuan kriteria alokasi mengerucut menjadi 2 (dua) proposal saja, satu mewakili negara-negara penangkap ikan jarak jauh (distant water fishing nations) dan satu proposal lagi mewakili negara-negara pantai di Samudera Hindia seperti Maladewa, Afrika Selatan, Australia, Mozambik, Pakistan, Srilanka dan lain-lain (IOTC 2018). Walaupun sudah mengalami berbagai perubahan dan penyempurnaan tetapi kriteria alokasi yang digunakan di antara ke dua proposal tersebut dapat ditelusuri persamaan dan perbedaannya dalam kajian berikut.

\section{Kriteria Alokasi Kuota yang Sama}

Jepang menjadi negara anggota dua tahun setelah IOTC berdiri pada tahun 1996. Oleh sebab itu Jepang mendapat legitimasi untuk beroperasi di Samudera Hindia (IOTC 2015). Indonesia baru menjadi anggota pada tahun 2007 sehingga walaupun secara alamiah memiliki yurisdiksi sebagai negara pantai namun sebelum 2007 tidak memperoleh legitimasi untuk menangkap tuna di laut bebas yang berbatasan dengan ZEE Indonesia. Itu sebabnya walau kedua proposal mengajukan kriteria sejarah penangkapan, namun usulan Indonesia adalah 5 tahun sedangkan Jepang adalah 10 tahun.

Persamaan berikutnya adalah kepatuhan terhadap resolusi pengelolaan yang dikeluarkan oleh IOTC. Berdasarkan laporan kepatuhan terhadap resolusi IOTC, Indonesia dapat mematuhi 39 sedangkan kepatuhan dari Jepang mencapai 60 dari 84 informasi kepatuhan yang digunakan. Faktor teknologi yang mendukung serta pengetahuan pelaku usaha dan nelayan yang luas menjadikan kesadaran akan pentingnya pendataan serta penelitian. Itu sebabnya tingkat kepatuhan Jepang lebih tinggi dibandingkan Indonesia.

Kriteria rencana perikanan berkelanjutan yang diajukan Jepang merupakan TAC yang dicadangkan sebesar $3 \%$ yang akan terus meningkat hingga $12 \%$ dalam jangka waktu 9 tahun. Indonesia tidak mengajukan hal ini sebagai kriteria namun mengusulkan adanya pencadangan TAC sebesar 2,5\% tiap tahunnya untuk stok cadangan yang akan meningkat hingga $10 \%$ (tanpa target waktu).

\section{Perbedaan dengan Kriteria Alokasi Yang Diajukan Indonesia}

Proposal Indonesia mengangkat dependensi negara berkembang yang menggunakan hasil tangkapannya sebagai komoditi ekspor untuk mendatangkan devisa bagi perekonomian negara. Adapun Jepang menggunakan hasil tangkapannya untuk konsumsi dalam negeri. Selanjutnya Indonesia mengedepankan posisi geografis yang tidak hanya langsung memiliki jurisdiksi mengelola ZEE Samudera Hindia, tetapi juga berarti memiliki signifikasi bio-ekologi perairan. Sedangkan sebagai negara penang- 
kap ikan jarak jauh, maka Jepang bukan negara pantai di Samudera Hindia. Dengan demikian Jepang (dan negara-negara Uni Eropa) juga tidak akan memenuhi kriteria negara anggota yang ZEE-nya merupakan perairan yang signifikan bagi kehidupan ikan tuna di Samudera Hindia.

Negara anggota IOTC yang tidak berbatasan langsung dengan Samudera Hindia didominasi oleh negara maju (Jepang, Korea Selatan, dan Uni Eropa). Sebagai negara maju, Jepang memiliki Indeks Pembangunan Manusia (IPM) sebesar 0,891 (peringkat 20 dunia), sedangkan Indonesia berada pada angka 0,689 dan menduduki peringkat 113 dari 188 negara (UNDP 2015). Ketimpangan nilai IPM ini menjadi kriteria yang diajukan Indonesia.

\section{Perbedaan dengan Kriteria Alokasi Yang Diajukan Jepang}

Jepang mengajukan kriteria alokasi berdasarkan kontribusi finansial. Baik kepatuhan terhadap pembayaran kontribusi keanggotaan, kontribusi keuangan maupun kontribusi ter- hadap riset dan pendataan. Bila kriteria ini diadopsi, maka nilai Indonesia akan lebih besar dari Jepang. Karena hasil tangkapan Indonesia lebih besar maka semakin besar kontribusi yang harus diberikan pada IOTC.

Perbandingan kriteria alokasi kuota diantara kedua negara tersebut tertera pada Tabel 3. Terlihat bahwa walaupun terdapat persamaan pada beberapa kriteria alokasi, namun penilaian ataupun pembobotan yang diberikan sangat berbeda.

\section{Simulasi Perhitungan Kuota Berdasarkan Kriteria Alokasi}

Simulasi perhitungan alokasi yang akan diperoleh bila menggunakan kriteria yang diajukan Indonesia disajikan dalam Tabel 4. Adapun perhitungan menggunakan kriteria alokasi Jepang disajikan dalam Tabel 5.

Hasil perhitungan menunjukkan alokasi kuota untuk kedua negara sama-sama menurun dengan kedua kriteria alokasi. Indonesia akan mengalami penurunan alokasi kuota se-

Tabel 3 Perbandingan kriteria alokasi kuota Indonesia dan Jepang

\begin{tabular}{|c|c|c|c|c|c|}
\hline Kriteria & \multicolumn{3}{|c|}{ Indonesia } & \multicolumn{2}{|c|}{ Jepang } \\
\hline Sejarah & \multicolumn{3}{|c|}{5 tahun } & \multicolumn{2}{|c|}{10 tahun } \\
\hline Keanggotaan & $\begin{array}{c}\mathrm{Ya} \\
0,90\end{array}$ & & $\begin{array}{l}\text { Tidak } \\
0,85\end{array}$ & $\begin{array}{c}\text { CP } \\
100 \%\end{array}$ & $\begin{array}{l}\text { CNP } \\
95 \%\end{array}$ \\
\hline Kepatuhan & $\begin{array}{c}\text { Patuh } \\
0,1\end{array}$ & $\begin{array}{l}\text { Sebagian } \\
\quad 0,05\end{array}$ & $\begin{array}{c}\text { Tak Patuh } \\
0\end{array}$ & $\begin{array}{l}\text { Patuh } \\
100 \%\end{array}$ & $\begin{array}{c}\text { Tak Patuh } \\
95 \%\end{array}$ \\
\hline $\begin{array}{l}\text { Rencana } \\
\text { berkelanjutan }\end{array}$ & \multicolumn{3}{|c|}{$2,5 \%$ meningkat menjadi $10 \%$} & \multicolumn{2}{|c|}{$\begin{array}{c}3 \% \text { menjadi } 12 \% \text { dalam } 9 \\
\text { tahun }\end{array}$} \\
\hline $\begin{array}{l}\text { Ketergantungan } \\
\text { ekonomi }\end{array}$ & $\begin{array}{c}\text { Tinggi } \\
0,3\end{array}$ & $\begin{array}{c}\text { Sedang } \\
0,25\end{array}$ & $\begin{array}{l}\text { Rendah } \\
0,2\end{array}$ & - & - \\
\hline $\begin{array}{l}\text { Negara pantai } \\
\text { S. Hindia }\end{array}$ & $\begin{array}{c}\mathrm{Ya} \\
0,25\end{array}$ & & $\begin{array}{l}\text { Tidak } \\
0,15\end{array}$ & - & - \\
\hline $\begin{array}{l}\text { Bio-ekologi } \\
\text { Perairan }\end{array}$ & $\begin{array}{c}\mathrm{Ya} \\
0,25\end{array}$ & & $\begin{array}{c}\text { Tidak } \\
0,15\end{array}$ & - & - \\
\hline IPM & $\begin{array}{c}\text { Tertinggal } \\
0,20\end{array}$ & $\begin{array}{c}\text { Berkembang } \\
\quad 0,15\end{array}$ & $\begin{array}{l}\text { Maju } \\
0,1\end{array}$ & - & - \\
\hline $\begin{array}{l}\text { Pemanfaatan } \\
\text { Alokasi }\end{array}$ & - & - & - & $\begin{array}{c}\leq 50 \%= \\
90 \%\end{array}$ & $\begin{array}{c}>50 \%= \\
100 \%\end{array}$ \\
\hline $\begin{array}{l}\text { Tunggakan } \\
\text { Kontribusi }\end{array}$ & - & - & - & $\begin{array}{l}\geq 2 \text { tahun } \\
=(50 \%)\end{array}$ & $\begin{array}{c}<2 \text { tahun }= \\
\text { tetap } \\
(100 \%)\end{array}$ \\
\hline Besaran Kontribusi & - & - & - & $\begin{array}{c}\geq \text { US } \$ \\
100,000= \\
105 \%\end{array}$ & $\begin{array}{c}<\text { US } \$ \\
100,000= \\
100 \%\end{array}$ \\
\hline
\end{tabular}


Tabel 4 Hasil perhitungan alokasi kuota tuna dengan kriteria alokasi Indonesia

\begin{tabular}{|c|c|c|c|c|c|c|c|c|c|c|}
\hline \multirow{2}{*}{ Negara } & \multirow{2}{*}{$\begin{array}{l}\text { Jenis } \\
\text { ikan }\end{array}$} & \multirow{2}{*}{$\begin{array}{l}\text { Rata- } \\
\text { rata } \\
\text { tangkap } \\
\text { an } 5 \\
\text { tahun } \\
\text { (ton) }\end{array}$} & \multicolumn{6}{|c|}{ Penilaian kriteria } & \multirow{2}{*}{$\begin{array}{l}\text { Kuota } \\
\text { yang } \\
\text { didapat } \\
\text { (ton) }\end{array}$} & \multirow{2}{*}{$\begin{array}{l}\text { Persen } \\
\text { tase } \\
\text { kuota } \\
\text { yang } \\
\text { didapa } \\
\text { t }\end{array}$} \\
\hline & & & KE & IPM & CS & BioE & CPCs & Co & & \\
\hline \multirow{2}{*}{ Indonesia } & YFT & 50.407 & \multirow{2}{*}{0,25} & \multirow{2}{*}{0,15} & \multirow{2}{*}{0,25} & \multirow{2}{*}{0,25} & \multirow{2}{*}{0,9} & \multirow{2}{*}{0,05} & 43.097 & \multirow{2}{*}{$85,5 \%$} \\
\hline & BET & 30.566 & & & & & & & 26.133 & \\
\hline \multirow{2}{*}{ Jepang } & YFT & 4.085 & \multirow{2}{*}{0,25} & \multirow{2}{*}{0,1} & \multirow{2}{*}{0,15} & \multirow{2}{*}{0,15} & \multirow{2}{*}{0,9} & \multirow{2}{*}{0,1} & 2.655 & \multirow{2}{*}{$65 \%$} \\
\hline & BET & 5.432 & & & & & & & 3.530 & \\
\hline
\end{tabular}

Keterangan:

$\mathrm{YFT}=$ yellowfin tuna, $\mathrm{BET}=$ bigeye tuna. $\mathrm{KE}=$ Ketergantungan ekonomi, BioE $=$ bio-ekologi, IPM= Indeks Pembangunan Manusia, $\mathrm{CS}=$ negara pantai, $\mathrm{CPCs}=$ Anggota IOTC, $\mathrm{Co}=$ Kepatuhan

Tabel 5 Hasil perhitungan alokasi kuota tuna dengan kriteria alokasi Jepang

\begin{tabular}{|c|c|c|c|c|c|c|c|c|c|}
\hline \multirow[b]{2}{*}{ Negara } & \multirow{2}{*}{$\begin{array}{l}\text { Jenis } \\
\text { ikan }\end{array}$} & \multirow{2}{*}{$\begin{array}{l}\text { Rata- } \\
\text { rata } \\
\text { tangkap } \\
\text { an } 10 \\
\text { tahun } \\
\text { (ton) } \\
\end{array}$} & \multicolumn{5}{|c|}{ Penilaian kriteria } & \multirow{2}{*}{$\begin{array}{l}\text { Kuota } \\
\text { yang } \\
\text { didapat } \\
\text { (ton) }\end{array}$} & \multirow{2}{*}{$\begin{array}{l}\text { Persentas } \\
\text { e kuota } \\
\text { yang } \\
\text { didapat }\end{array}$} \\
\hline & & & CPCs & Co & $T$ & CF & PA & & \\
\hline \multirow{2}{*}{ Indonesia } & YFT & 42.074 & \multirow{2}{*}{$100 \%$} & \multirow{2}{*}{$95 \%$} & \multirow{2}{*}{$100 \%$} & \multirow{2}{*}{$105 \%$} & \multirow{2}{*}{$100 \%$} & 40.511 & \multirow{2}{*}{$97 \%$} \\
\hline & BET & 24.036 & & & & & & 23.256 & \\
\hline \multirow{2}{*}{ Jepang } & YFT & 7.126 & \multirow{2}{*}{$100 \%$} & \multirow{2}{*}{$105 \%$} & \multirow{2}{*}{$100 \%$} & \multirow{2}{*}{$105 \%$} & \multirow{2}{*}{$100 \%$} & 7.621 & \multirow{2}{*}{$107 \%$} \\
\hline & BET & 8.954 & & & & & & 9.575 & \\
\hline
\end{tabular}

Keterangan:

$\mathrm{YFT}=$ yellowfin tuna, $\mathrm{BET}=$ bigeye tuna. $\mathrm{T}=$ tunggakan, $\mathrm{CF}=$ kontribusi finansial,

$\mathrm{PA}=$ Pemanfaatan alokasi, $\mathrm{CPCs}=$ Anggota IOTC, $\mathrm{Co}=$ Kepatuhan

besar $14,5 \%$ bila menggunakan kriteria yang diusulkan, tapi hanya turun sebesar $3 \%$ bila menggunakan perhitungan kriteria alokasi Jepang. Namun karena data rata-rata hasil tangkapan yang digunakan memiliki rentang waktu yang berbeda, yaitu 5 tahun dan 10 tahun, maka nilai hasil tangkapan rata-rata yang digunakan sebagai dasar perhitungan berbeda signifikan. Untuk kriteria Indonesia rata-rata hasil tangkapan dalam 5 tahun terakhir adalah 50.407 ton, sedangkan rata-rata untuk 10 tahun adalah 42.074 ton. Oleh karenanya walaupun mengalami penurunan alokasi kuota hampir $15 \%$, tetapi nilai kuotanya sebesar 43.097 ton tetap lebih besar dari perhitungan dengan kriteria Jepang yang hanya turun $3 \%$ tapi nilai kuotanya hanya 40.511 ton. Terdapat perbedaan kurang lebih $6 \%$.

Bila data yang digunakan Indonesia mengalami perubahan, pembobotan dapat saling menutupi. Misalnya, bila IPM Indonesia tergolong negara maju hal tersebut dapat tertutupi jika Indonesia dapat meningkatkan nilai kepatuhan terhadap resolusi yang berlaku. Dilihat dari jangka panjang, usulan yang diajukan oleh Jepang bisa saja menguntungkan Indonesia bila sejarah penangkapan Indonesia dalam 10 tahun terus meningkat dari sebelumnya dan nilai kepatuhan Indonesia tergolong patuh. Hal tersebut karena pembobotan dari kontribusi finansial dan kepatuhan negara dapat meningkatkan alokasi kuota tuna dan Indonesia merupakan negara yang memberikan kontribusi terbesar ketiga pada tahun 2015.

Jepang akan mengalami kerugian yang sangat besar bila menerima kriteria alokasi usulan Indonesia yaitu sebesar 35\%. Apabila menggunakan kriteria yang diajukannya, maka alokasinya akan meningkat sebesar $7 \%$. Hal ini disebabkan oleh dua kriteria Jepang yang dapat meningkatkan alokasi kuota tuna, yaitu kepatuhan dan kontribusi finansial.

\section{Kepatuhan terhadap Berbagai Resolusi dan Ketentuan IOTC}

Kriteria keanggotaan dan sejarah penangkapan perlu menjadi perhatian Indonesia karena keduanya saling terkait. IOTC menilai Jepang patuh (compliance) karena data kapal dengan hasil tangkapan Jepang selaras, sedangkan Indonesia dinilai tidak patuh (non compliance). Indonesia melaporkan kapal yang terdaftar dan beroperasi di WPP 572, 573 dan 
laut lepas. Namun hasil tangkapan yang dilaporkan berasal dari WPP 571, 572, dan 573. Hal ini dinyatakan sebagai tidak selaras karena data tangkapan tidak melaporkan tangkapan dari laut lepas sedangkan kapal yang beroperasi di WPP 571 tidak terdaftar di IOTC.

Aspek kepatuhan perlu diwaspadai dan diantisipasi dengan baik agar mendapat kepercayaan dan dukungan dari negara anggota lainnya. Besar pembobotan perlu diatur sedemikian rupa sehingga dapat menguntungkan atau meningkatkan nilai pembobot Indonesia. Jumlah kapal dan hasil tangkapan yang besar serta persiapan data yang akurat dapat memperkuat posisi Indonesia saat melakukan negosiasi. Bila hal tersebut dapat dipersiapkan dengan baik, kuota yang didapatkan Indonesia tidak turun jauh dari hasil tangkapan sebelumnya.

\section{Kepatuhan terhadap Berbagai Kriteria Finansial}

Kriteria alokasi yang diusulkan oleh Jepang dapat menguntungkan Indonesia, yaitu tingkat kepatuhan dalam kontribusi finansial, pemanfaatan alokasi kuota dan prediksi pengelolaan TAC. Indonesia merupakan negara terbesar ketiga pada tahun 2015 dalam memberikan kontribusi finansial. Bila kriteria kontribusi finansial dapat dimasukan dalam usulan Indonesai tentu dapat menguntungkan posisi Indonesia. Selain itu, negara pengembang distant water fishing pun banyak yang memberikan kontribusi besar, seperti Uni Eropa, China, dan Jepang. Negara-negara tersebut pastinya akan menyetujui hal tersebut karena dinilai dapat menguntungkan posisi negaranya.

\section{Negara Pantai sebagai Pemegang Yurisdiksi Pengelolaan ZEE}

Kriteria alokasi sebagai negara pantai yang memiliki jurisdiksi mengelola wilayah perairan yang memiliki signifikansi terhadap siklus hidup tuna diperkuat oleh Konvensi Hukum Laut Internasional 1982 khususnya mengenai hak-hak negara pantai. Hal tersebut merupakan kelebihan negara-negara pantai yang tidak dimiliki oleh negara-negara penangkap ikan jarak jauh (distant water fishing nation) yang hanya berdasarkan data sejarah hasil tangkapan.

Lebih jauh lagi, hak yang tercantum dalam Konvensi Hukum Laut Internasional 1982 dapat disandingkan dengan teori hak kepemilikian (property right). Dalam rezim kepemilikan sumber daya alam terdapat hak kepemilikan versi Schlager dan Ostrom (1992) diantaranya adalah: 1) Hak akses (Access right) merupakan hak untuk masuk ke wilayah sumber daya yang memiliki batas-batas yang jelas dan untuk menikmati manfaat non-ekstraktif; 2) Hak pemanfaatan (Withdrawal right) merupakan hak untuk memanfaatkan sumber daya atau hak untuk berproduksi; 3) Hak pengelolaan (Management right) yaitu hak untuk menentukan aturan operasional pemanfaatan sumber daya alam; 4) Hak ekslusi (Exclusion right) merupakan hak untuk menentukan siapa yang boleh memiliki hak akses dan bagaimana hak akses tersebut dialihkan ke pihak lain; 5) Hak pengalihan (Alienation right) yaitu hak untuk menjual atau menyewakan sebagian atau seluruh hak kolektif tersebut diatas.

Pasal 56 ayat 1 dalam Konvensi Hukum Laut Internasional 1982 menetapkan hak berdaulat negara-negara pantai untuk wilayah ZEE-nya. Lebih lanjut dinyatakan bahwa negara pantai mempunyai hak berdaulat untuk keperluan eksplorasi dan eksploitasi serta konservasi dan pengelolaan sumber kekayaan alam baik hayati maupun non hayati dari atas hingga dasar laut dibawahnya. Artinya negara-negara pantai mendapat hak untuk mengelola dan menentukan aturan operasional pemanfaatan sumber daya alam di wilayah ZEE-nya.

Menurut Schlager dan Ostrom (1992), pemegang hak pengelolaan memiliki wewenang untuk menentukan bagaimana, kapan dan dimana pengambilan dari sumber daya dapat terjadi, serta apakah dan bagaimana struktur sumber daya dapat diubah. Hal ini diperkuat oleh Konvensi Hukum Laut 1982 pasal 61 ayat 1 yang menyatakan bahwa negara pantai dapat menentukan seberapa besar jumlah hasil tangkapan yang dapat diperbolehkan di dalam wilayah ZEE-nya.

Bila antara coastal state dengan distant water fishing nation belum menemukan titik tengah sedangkan sistem alokasi mendesak harus dilaksanakan jalur voting dapat saja dilakukan. Tertulis dalam persetujuan IOTC bahwa pengambilan suara diputuskan bila mencapai $2 / 3$ dari seluruh anggota IOTC yang hadir dan memberikan suara (IOTC 2014). Dilihat dari seluruh negara anggota IOTC, terdapat 20 negara yang berbatasan dengan Samudera Hindia sedangkan 13 negara tidak berbatasan langsung. Jika Indonesia dapat meyakinkan seluruh coastal state, maka usulan yang diajukan oleh Indonesia dapat diterima. Dalam hal pembagian kuota Indonesia memiliki posisi yang kuat hal ini ditunjukkan dengan hasil tangkapan tuna Indonesia berada pada posisi ketiga. Indonesia memiliki garis pantai cukup panjang yang berbatasan langsung dengan Samudera Hindia. Namun nampaknya perundingan diupayakan untuk tidak diarahkan pada pengambilan 
keputusan melalui voting. Hal ini menjadi semakin jelas ketika pertemuan Komisi Teknis tahun 2018 berakhir tanpa adanya keputusan untuk melakukan pemilihan kriteria yang akan digunakan (IOTC 2018).

Dalam perundingan yang dilakukan sejak tahun 2011, sulit mendapatkan pandangan yang sama antara negara-negara pantai dengan negara pemiliki armada penangkap jarak jauh. Perundingan Komisi Teknik ke empat yang seharusnya dilaksanakan bulan Februari 2017 di Afrika Selatan ditunda sampai bulan Februari 2018. Kriteria alokasi yang diajukan coastal state memberikan nilai tinggi pada aspek keterkaitan geografis sedangkan distant water fishing nation lebih mengarah pada sejarah, pendataan dan kepatuhan. Seiring berjalannya waktu, tingkat kepatuhan dalam kontribusi finansial, pemanfaatan alokasi kuota tuna dan prediksi pengelolaan TAC dapat dijadikan celah bagi Indonesia untuk meningkatkan alokasi kuota tuna. Kriteria ini pun bisa meyakinkan negara lain khususnya distant water fishing nation seperti Jepang agar menerima usulan yang diajukan oleh Indonesia. Usulan Jepang yang dapat menguntungkan Indonesia perlu dipertimbangkan untuk usulan kriteria alokasi kuota tuna berikutnya sehingga usulan Indonesia dapat dinilai telah mempertimbangkan seluruh aspek secara utuh, yaitu ekonomisosial, keadilan, kepatuhan, dan konservasi.

Dalam pertemuan Komisi Teknik ke-3 tahun 2016 di Iran terdapat agenda pertemuan coastal state IOTC yang biasa dikenal dengan G16. G16 telah melakukan pertemuan dan menyepakati prinsip dasar pembagian alokasi kuota tuna, yaitu mengenai perikanan berkelanjutan, ketahanan pangan khususnya bagi negara pesisir berkembang dan pulau-pulau kecil, hak berdaulat coastal state, pemanfaatan laut lepas harus memfasilitasi coastal state berkembang. Namun ketika hal ini dikemukakan dalam pertemuan TCAC III, negaranegara distant water fishing nation tidak setuju. Selama pertukaran pandangan dalam pertemuan TCAC III, terdapat perbedaan sudut pandang antara coastal state dengan distant water fishing nation (IOTC 2016).

Perbedaan tersebut terutama dalam pembobotan kriteria diantaranya, negara distant water fishing fleet memberikan bobot yang sangat signifikan terhadap kepatuhan sedangkan banyak negara yang masih kesulitan untuk meningkatkan kepatuhan terutama bagi negara berkembang sehingga negara pantai tidak menerima pembobotan yang terlalu tinggi. Begitu pula mengenai sejarah penangkapan (historical catch) distant water fishing nation yang ditangkap di ZEE negara pantai. Negara pantai mengatakan bahwa tangkapan di ZEE harus dicatat sebagai hasil tangkapan negara pantai tanpa mempertimbangkan bendera kapal penangkap ikan yang beroperasi di ZEE negara pantai. Namun distant water fishing nation beranggapan ikan di ZEE harus dianggap sebagai hasil tangkapan negara bendera (flag state) karena telah lama memanfaatkan sumberdaya ikan di Samudera Hindia (IOTC 2016). Pada pertemuan tersebut, Uni Eropa telah mengajukan proposal baru sebagai alternatif penentuan kriteria alokasi kuota.

Pada pertemuan TCAC IV bulan Februari 2018 di Seychelles, proposal penentuan kriteria alokasi penangkapan tuna mengerucut menjadi dua usulan. Satu proposal diusung oleh negara-negara penangkap ikan jarak jauh dan satu lagi proposal yang diusung negara-negara pantai di Samudera Hindia. Laporan hasil akhir pertemuan tersebut menyatakan bahwa walaupun semua negara sepakat menggunakan dasar konvensi Hukum Laut 1982 dan konvensi mengenai stok ikan yang beruaya jauh, tetapi tetap tidak tercapai kesepakatan tentang perhitungan sejarah penangkapan di wilayah ZEE Samudera Hindia. Demikian pula mengenai perbedaan perekonomian antara negara berkembang dengan negara maju yang disepakati dapat dijadikan kriteria alokasi, tetapi belum disepakati bagaimana melakukan pembobotan perhitungannya. Akhirnya pertemuan tersebut menyepakati untuk dilakukannya simulasi perhitungan terhadap kedua proposal tersebut dengan menggunakan data hasil tangkapan sejak tahun 1950 sampai dengan 2016. Hasil perhitungan simulasi kedua proposal tersebut akan menjadi bahan pertimbangan rapat Komisi Teknik berikutnya.

Perundingan dan diplomasi Indonesia telah meyakinkan negara-negara pantai anggota IOTC untuk mendorong pemberian prioritas alokasi kuota pada negara pantai sebagai konsekuensi logis dan alamiah terkait posisi geografis dan status hukum internasional untuk perairan dimaksud (ZEE). Saat ini Indonesia perlu melakukan simulasi perhitungan sebagaimana diputuskan oleh Rapat Komisi Teknis tersebut di atas untuk dapat menentukan strategi negosiasi selanjutnya.

\section{KESIMPULAN}

Kriteria alokasi kuota Indonesia mengutamakan kedudukan dan jurisdiksi negara pantai serta ketergantungan ekonomi dan tingkat pembangunan manusianya. Adapun kriteria alokasi kuota Jepang lebih mengutamakan sejarah pemanfaatan sumber daya, kepatuhan 
terhadap resolusi dan kontribusi finansial terhadap IOTC.

Bagi Indonesia, kriteria alokasi kuota yang diusulkan akan memberikan alokasi tangkapan yang lebih tinggi dibandingkan bila menggunakan kriteria alokasi kuota yang diusulkan oleh Jepang.

\section{SARAN}

Menyikapi perkembangan perundinganperundingan IOTC diberbagai tingkatan, Indonesia harus tetap aktif mengikuti pembahasan penyusun mekanisme pengelolaan stok tuna lainnya (pengaturan rumpon, pengaturan kapasitas tangkapan, penggunaan kapal suplai, penutupan wilayah tertentu, dan lain sebagainya), sebagai upaya mencari solusi alternatif menghadapi Rapat Komisi Teknis ke-5. Indonesia juga harus segera melakukan simulasi perhitungan sebagaimana diputuskan dalam pertemua terakhir.

\section{UCAPAN TERIMA KASIH}

Penulis mengucapkan terima kasih kepada pimpinan dan para anggota delegasi Indonesia dalam berbagai pertemuan Komisi Teknis untuk Kriteria Alokasi untuk IOTC yang telah bersedia menjadi responden dan memberikan informasi yang sangat berharga bagi penelitian ini. Penulis juga mengucapkan terima kasih kepada para Reviewer serta semua pihak yang telah membantu terwujudnya tulisan ini.

\section{DAFTAR PUSTAKA}

Aranda M, Murua H, Bruyn P. 2012. Managing Fishing Capacity in Tuna Regional Fisheries Management Organisations (RFMOs): Development and State of the Art. Marine Policy, Elsevier. 36(5): 985992.

Bailey M, Ishimura G, Paisley R, Sumaila UR. 2013. Moving Beyond Catch in Allocation Approaches for Internationally Shared Fish Stocks. Marine Policy, Elsevier. 40: 124-136.

Gagern A, Van den Berg J. 2013. A Critical Review of Fishing Agreements with Tropical Developing Countries. Marine Policy, Elsevier. 38: 375-386.

Gigentika S, Nurani TW, Wisudo SH, Haluan John. 2017. Sistem Pemanfaatan Ikan Tuna di Nusa Tenggara. Marine Fisheries. 8(1): 24-37.
Haward M, Bergin A. 2001. The Political Economy of Japanese Distant Water Tuna Fisheries. Marine Policy, Elsevier. 25: 91101.

Hidayati S. Dwidjono HD, Masyhuri, Kamiso HN. 2015. Analysis of Deteminant Indone-sian Tuna Fish Competitiveness in Japanese Market. International Journal of Agriculture System (IJAS). 3(2): 169178.

(IOTC) Indian Ocean Tuna Commission. 2009. Report of the Twelfth Session of the Scientific Committe [Internet]. [diunduh April 2017] Tersedia pada: http://iotc.org/ documents.

2010. Report of the Fourteenth Session of the Indian Ocean Tuna Commission, Busan South Korea. [Internet]. [diunduh April 2017] Tersedia pada: http://iotc.org/documents.

2012. Proposal on IOTC Quota Allocation Criteria Japan [Internet]. [diunduh Desember 2016]. Tersedia pada: http://iotc.org/documents.

2013. Report of the 2nd Techical Committee on Allocation Criteria [Internet]. [Muscat, Oman, 18-20 February 2013]. [diunduh Desember 2016]. Tersedia pada: http://iotc.org/documents.

. 2014. Indian Ocean Tuna Commission: Rules of Procedure (20140 [Internet]. [diunduh Januari 2017]. Tersedia pada: http://iotc.org/about-iotc/basic-texts.

2015. Japan National Report to The Scientific Committe IOTC [Internet]. [Japan, 10 November 2015]. [diunduh Maret 2017] Tersedia pada: http://iotc.org/documents.

2016. Report of the 3rd Techical Committee on Allocation Criteria [Internet]. [Kish Island, Islamic Republic of Iran, 21-23 February 2016]. [diunduh Maret 2017] Tersedia pada: http://iotc. org/ documents.

.2018. Report of the 4th Technical Committee on Allocation Criteria [Internet]. [Victoria, Mahé, Seychelles, 5-7 February 2018]. [diunduh Maret 2018]. Tersedia pada: http://iotc.org/documents.

Irianto HE, Wudianto, Nugraha B, Widodo AA, Satria F, Sadiyah L.2015. Indonesia National Report to The Scientific Committe IOTC. 
Lynham J. 2014. How Have Catch Share Been Allocated?. Marine Policy, Elsevier. 44: 42-48.

Nazir M. 2014. Metode Penelitian. Jakarta (ID): Ghalia Indonesia.

Nichols R, Yamazaki S, Jennings S, Watson RA. 2015. Fishing Access Agreements and Harvesting Decisions of Host and Distant Water Fishing Nations. Marine Policy, Elsevier. 54: 77-85.

Noye J, Mfodwo K. 2012. First Steps Towardsa Quota Allocation System in the Indian Ocean. Marine Policy, Elsevier. 36(4): 882-894.

Nurani TW, Murdaniel RPS, Harahap MH. 2013. Upaya Penanganan Mutu Ikan Tuna Segar Hasil Tangkapan Kapal Tuna Longline untuk Tujuan Ekspor. Marine Fisheries. 4(2): 153-162.

Queirolo LE, Johnston RS. 1989. Distant Water Fishing Nations and Extended Fisheries Jurisdiction. Marine Policy, Elsevier. 13(1): 16-21.
Sunoko R, Huang HW. 2014. Indonesia Tuna Fisheries Development and Future Strategy.Marine Policy, Elsevier. 43: 174183.

Schlager E, Ostrom E. 1992. Property Rights Regimes and Natural Resources: a. Conceptual Analysis. Land Economics, University of Wisconsin Press. 68(3): 249-262.

[UN] United Nations, 1982. United Nations on the Law of the Sea [internet]. [diunduh Desember 2016]. Tersedia pada: http:// www.un.org/depts/los/convention_agree ments/texts/unclos/unclos_e.pdf.

[UNDP] United Nation Development Program. 2015. Human Development Report 2015: Work Human Development [Internet]. New York (US): UNDP Tersedia pada: http://hdr.undp.org/en/countries.

Wardono B. 2016. Efisiensi, Produktivitas dan Indeks Ketidakstabilan Perikanan Tuna Longline dan Pancing Tonda. Marine Fisheries. 7 (1): 1-11. 